\title{
FINANCIAL FITNESS OF SELECTED PHARMACEUTICALS COMPANIES OF BANGLADESH: A COMPARATIVE ASSESSMENT
}

\author{
Sultana Akter \\ Assistant Professor \\ Department of Business Administration \\ Int'l Islamic University Chittagong, Bangladesh \\ E-mail: sa_maya@rocketmail.com
}

\begin{abstract}
To understand the financial condition of a firm, it is mandated to evaluate the financial fitness of a firm, whether manufacturing, trading and service rendering etc. The main purpose of this research is to measure the financial fitness of leading pharmaceutical industries and listed on the stock exchange in Bangladesh. This study employs a sample of seven companies from pharmaceutical industries in Bangladesh where Altman's Z-score model is used to assess the financial fitness of those companies by the prediction of whether they will go into bankruptcy within the next two years. By applying the model, it is revealed that SQUARE Pharmaceuticals Ltd, Renata Limited and IBN SINA Pharmaceutical Limited are in a very good position with higher Z-Score. Beacon Pharmaceuticals Limited and Ambee Pharmaceuticals Limited are heading toward good scores. But ACI Limited and Beximco Pharmaceuticals Limited are financially unhealthy and there is a possibility of going into bankruptcy in the near future. The finding of the study suggested the main reason for such a situation is that the performance of companies is differed by declining market value of shares, falling total asset turnover, inadequate proportion of EBIT to total assets and insufficient liquid assets etc.
\end{abstract}

Keywords: Financial Fitness, Altman Z-Score, Bankruptcy, Pharmaceutical Company.

JEL Classification Codes: G33, G53, M10.

\section{INTRODUCTION}

Bangladesh is one of the least developed countries which meets about $98 \%$ of its demand for pharmaceutical products. It has a market size of nearly BDT 200 billion. Bangladeshi pharmaceutical products are exported to 147 countries. This industry contributes about $1.85 \%$ of total GDP. The industry has undergone remarkable transformations in recent years, and it is now the most successful manufacturing industry in the country (Faisal, 2019). The industry is growing due to the increase in per capita income of the people, their hectic daily activities, an aging population, changing lifestyles and economic status, unhealthy eating habits, increasing incidence of chronic diseases etc. which provide industry players an opportunity to grow. Bangladesh's pharmaceuticals market size will reach more than BDT 400 billion by 2023 (Niti, 2019).

SQUARE Pharmaceuticals Ltd (2020) started its business in 1958 and after 33 years of establishment it was changed into a public limited company in 1991. In 1995, it was listed on stock exchanges. It has a market share of $16.95 \%$ and a turnover of BDT 50.87 billion. Square Pharmaceuticals Limited exports medicines from Bangladesh to 42 countries. The objective of the company is to conduct transparent business operations within a legal and social framework. It has exported pharmaceutical products since 1995 and provides quality products. It also offers service for 
product development and provides assistance in product promotion. Renata Limited (2020), one of the fastest growing and foremost pharmaceutical companies in Bangladesh, was established in 1972 as Pfizer (Bangladesh) Limited. It was listed on the Dhaka Stock Exchange. It has a market capitalization of approximately Taka 87 billion. The company exports its products to many countries around the globe. The company focuses on long-term growth and goes the extra mile for employees. Caring for employees, assisting disadvantaged members and building a sustainable environment is the main corporate social responsibility of the company. Beacon Pharmaceuticals Limited (2020) opened its business in 2006 with the aim of delivering and developing innovative and life-saving medicines to fight various life-threatening diseases. It was listed on the Dhaka and Chittagong stock exchanges. It has a premium infrastructure \& framework designed by European engineers. The IBN SINA Pharmaceutical industry Ltd (2020) was established with modern art and technology in 1983 in Gazipur. The company is outfitted with high-quality machinery and has established itself as a leader in the pharmaceutical industry in Bangladesh. It has two manufacturing segments like Pharmaceutical and organic or herbal Medicine Manufacturing Plant. Highest quality medicines at an affordable price are the primary objective of IBN SINA. The Advanced Chemical Industries Ltd (ACI) is one of Bangladesh's largest companies, having been founded on January 24, 1973.It has four business segments such as ACI Agribusiness, ACI Retail Chain, ACI Consumers brands, and ACI pharmaceuticals. ACI Pharmaceuticals is excited about combining knowledge, expertise, and modern technology to lead a quality health care system in Bangladesh (ACI Ltd., 2020). Ambee Pharmaceuticals Limited (2020) was established in 1976. It was incorporated on 4th February 1976. It is registered under the companies Act 1913 as a public limited company. It has got its own distribution network throughout the country and a Quality Management System is followed to ensure consistent quality. They meet all National Regulatory Requirements and follow Good Manufacturing Practices (GMP) in their business as recommended by the World Health Organization. Beximco Pharmaceuticals Ltd (Beximco Pharma) was established in 1976 and commenced its operations in 1980. It is a public limited company listed on the Dhaka Stock Exchange. It is headquartered in Dhanmondi. The mission of the company is to enhance human health and well-being by providing affordable and contemporary medicine. The core values of the company are commitment to quality, customer satisfaction, people focus, accountability and corporate social responsibility (Beximco Pharma, 2020).

Based on the foregoing, it is high time to assess and scrutinize the performance of pharmaceutical companies. But performance evaluation is a dynamic matter rather than static as performance has changes yearly, monthly, daily, even within a moment (Majumder \& Rahman, 2011). This study is undertaken to evaluate the performance of some selected listed pharmaceutical companies in Bangladesh. This will provide insight into the company's financial situation and position in comparison. The use of a model to assess the financial condition of the company will assist management in taking corrective measures in the future, potentially reducing bankruptcy. It will even help creditors, shareholders and regulatory agencies to a great extent. Many studies have been undertaken in the past and among them, Edward Altman's Z-Score is the most popular Z-Score is a multi-discriminate analysis. While doing the review of literature on this area, it was found that a few studies have been done using Z-Score in Bangladesh. That's why this study emphases on analyzing the financial fitness of selected pharmaceutical companies which are listed on the Dhaka Stock Exchange in Bangladesh (Ray, 2011).

\section{LITERATURE REVIEW}

A lot of research has gone into studying and scrutinizing the financial fitness of companies by researchers in different parts of the world. The literature in this study mostly involves research depending on the published work existing in Bangladesh as well as abroad. A study used the Z-score model to analyze the financial health of five Indian pharmaceutical companies over the course of 11 years. This model revealed that Ranbaxy Lab Ltd. and GlaxoSmithKline Pharmaceuticals Ltd. were 
in good financial health, while the other three companies needed to focus on improving financial performance, particularly in terms of sales revenue generation and asset utilization in the future (Panda $\&$ Behera, 2015). Akbar conducted a study to predict financial health conditions on stock returns using the panel data regression method for seven Indonesian stock exchange companies. The results showed that there is a decrease in financial ratios in each company and this has implications for the decline in the financial distress model (Akbar et al., 2019). Another study used Edward I Altman's Z-Score model on selected Indian Pharmaceutical companies for the period of 10 years. Statistical tools and financial techniques are used to analyze a company's financial health performance and decide that there are no chances of any bankruptcy in the near future as all are in a safe or healthy zone (Geethalakshmi \& Jothi,2017). Nsiah conducted a study to compare two pharmaceutical companies listed on the Ghana stock exchange based on the profitability, liquidity, solvency and probability of that company. It was found that the efficiency of Aryton is declining in the case of management in utilizing the assets, but Starwin is improving in this case. By using Altman's Z-score, it was also shown that Aryton was not in financial distress but Starwin was in financial distress and likely to be bankrupt in the near future (Nsiah \& Aidoo, 2015). A study on an industrial firm and used Altman Zscores and ratio analysis approaches to predict the firm's insolvency for the period of 2002-2004. The z-score from the analysis was less than 1.81 (z-score $<1.81$ which means the firm has increased its debt and will be facing bankruptcy in the near future (Al-Rawi et al., 2018). Mizan et al. (2011) has selected six leading pharmaceutical companies of Bangladesh listed on the DSE. They have used Altman Z-Score to predict, analyze and compare the financial soundness. The values of Z-Score and other financial trend analysis of the rest of the companies are found to be unsatisfactory and they have a significant likelihood of facing financial distress in the near future. Ahmed and Hasan (2019) used ratio analysis of three pharmaceutical companies in Bangladesh. Data has been collected from the annual financial reports of Beximco, Renata and SQUARE pharmaceutical companies from 2006 to 2010 and found that the financial position and operational performance of the selected pharmaceuticals are not satisfactory. Jannatunnesa (2016) attempted to analyze the financial consistency and the profitability determinants of pharmaceutical companies in Bangladesh. Altman's Z-score model was used for measuring the financial soundness of the pharmaceutical industry. It also examined the profitability determinants by testing a number of hypotheses. The results show that the insolvency possibility of almost every company is very high. The industry also has a high possibility of bankruptcy within the next two years. Dakhwani and Nayak (2017) focused on the financial position of selected companies of Pharmaceutical Industry in India on the basis of 10 years of data collected from financial statements of respective companies using Altman's Z-Score model. According to their analysis, some companies are found to be in the bankruptcy zone, whereas some are in a healthy zone and some have become bankrupt. Al Ali (2018) examined the financial soundness of the two healthcare companies listed on the Kuwait stock exchange. The results showed that both companies are positioned in the gray area, which means that they are facing bankruptcy risk. Mizan and Hossain (2014) found on a sample of five cement companies, found that two firms, Heidelberg cement and Confidence Cement of Bangladesh, are financially sound whereas the other three are not in a good position.

\section{RESEARCH QUESTIONS \& OBJECTIVES OF THE STUDY}

Based on the foregoing discussion, two research questions for this study have been identified:

- What is the financial position of the pharmaceutical industry in Bangladesh?

- How financial distress among the selected companies is measured using Altman Z-score ratios?

The ultimate objectives of the study are to get the answer to research questions as follows:

- To assess the financial situation of sample pharmaceuticals companies of Bangladesh

- To measure financial fitness by means of Altman's Z-score formula and compare the financial distress among selected pharmaceutical companies. 
- To highlight some findings and to recommend some measures regarding the financial position of selected companies.

\section{RATIONAL OF THE STUDY}

Determining the financial health of a firm is a very important corporate skill. It is important to know how the company is performing its business for a number of reasons. It is important to have a clear picture of the financial health of a company to make more effective strategic decisions about the organization's resource allocation and its direction. It also plays a significant role in attracting investors or for seeking finance.

The study can provide assistance to companies in evaluating their financial efficiency. It can also help investors in analyzing their investment decisions. Management can find out the financial problems and take steps for more effective and efficient utilization of resources. It will be helpful to investors in taking the decision to invest in specified companies.

\section{Data Collection}

\section{METHODOLOGY}

To conduct the study, secondary data has been gathered from the yearly reports of selected pharmaceutical companies from the year 2015-2019. The position of the company is analyzed based on various elements of ratio analysis. To predict the financial distress of the companies using ratio analysis, the Altman's Z-score model is used (Altman's Z-Score Model, 2020).

\section{Population \& Sample}

Bangladesh's own-grown pharmaceutical industry has met approximately $98 \%$ of the demand for pharmaceutical products. The industry is growing due to the increase in per capita income of the people, their hectic daily activities, aged population, change in lives and economic status, unconscious eating behaviors, growing rate of chronic diseases etc. which provides industry players an opportunity to grow There are a number of pharmaceutical businesses, about 50 plus operating in Bangladesh. Among them, around 32 companies are listed on the Dhaka Stock Exchange under the pharmaceutical and chemicals industry. Among all the listed pharmaceutical companies on the stock exchange, samples of seven companies were selected to conduct this study.

The sample pharmaceutical companies of this study are given below:

- SQUARE Pharmaceuticals Ltd

- Reneta Limited

- Beacon Pharmaceuticals Limited

- The IBN SINA Pharmaceutical Industry Ltd

- ACI Limited

- Ambee Pharmaceuticals Ltd

- Beximco Pharmaceuticals Ltd

\section{Method of Data Processing}

Altman's Z-score model was published by Edward I. Altman in 1968 to predict the bankruptcy of a business. The formula may be used to forecast the possibility of a company going into bankruptcy within the next two years. This model quantifies a company's financial fitness by using multiple corporate income and balance sheet values. The model was originally used by publicly held manufacturers and later it was used in private manufacturing, non-manufacturing and service companies. The model proved to be accurate for predicting bankruptcy on various occasions. The model has improved and has become a reliable predictor of bankruptcy.

The study is undertaken by using the Altman's Z-Score formula. The formula consists of five key financial ratios: $\mathrm{X}_{1}, \mathrm{X}_{2}, \mathrm{X}_{3}, \mathrm{X}_{4}$ and $\mathrm{X}_{5}$. These are independent variables which are computed and substituted in the formula to derive the Z-Score of each company. After the derivation of the Z-score, 
the values are compared to the benchmark set by the model to determine whether a company is in a safe, grey or distress zone. On the basis of analysis, it is found whether a company will be bankrupt in the near future. Lastly, the values of the Z-Score of each company are compared with the average Z-Score of each company to give a comparative analysis of the company's performance.

\section{The formula is used as follows:}

$\mathrm{Z}=1.2 \mathrm{X}_{1}+1.4 \mathrm{X}_{2}+3.3 \mathrm{X}_{3}+0.6 \mathrm{X}_{4}+1.0 \mathrm{X}_{5}$

Where:

$\mathrm{X}_{1}=$ Working capital/ total assets.

$\mathrm{X}_{2}=$ Retained Earnings /Total Assets.

$\mathrm{X}_{3}=$ Earnings before interest and taxes/total assets.

$\mathrm{X}_{4}=$ Market Value of equity/ book value of total liabilities.

$\mathrm{X}_{5}=$ Sales/ total assets.

The results obtained from the model are then compared to a benchmark that is set to determine the financial soundness of the company. The criteria used to interpret the Z-score model are:

\section{Zones of discrimination}

\begin{tabular}{|l|l|l|}
\hline Score & Zone & Description \\
\hline $\mathrm{Z}>2.99$ & Safety & Do not go for bankruptcy within next two years \\
\hline $1.80<\mathrm{Z}<2.99$ & Grey & $\begin{array}{l}\text { Reasonable chance to go for bankruptcy within next two } \\
\text { years }\end{array}$ \\
\hline $\mathrm{Z}<1.80$ & Distress/bankruptcy & Certainty goes for bankruptcy within two years. \\
\hline
\end{tabular}

\section{ANALYSIS \& FINDINGS}

\section{Altman Z-Score for SQUARE Pharmaceuticals Ltd.}

Table 1. Computation of Z-Score for SQUARE Pharmaceuticals Ltd.

\begin{tabular}{|l|l|l|l|l|l|l|}
\hline Variable/year & $\mathbf{2 0 1 5}$ & $\mathbf{2 0 1 6}$ & $\mathbf{2 0 1 7}$ & $\mathbf{2 0 1 8}$ & $\mathbf{2 0 1 9}$ & Mean \\
\hline $\mathrm{X}_{1}=$ Net Working Capital/Total Assets & 0.2325 & 0.3694 & 0.4100 & 0.4063 & 0.5430 & 0.3922 \\
\hline $\mathrm{X}_{2}=$ Retained Earnings/Total Assets & 0.6405 & 0.6880 & 0.6912 & 0.6925 & 0.7442 & 0.6913 \\
\hline $\mathrm{X}_{3}=$ EBIT/Total Assets & 0.2579 & 0.2273 & 0.1785 & 0.1448 & 0.1725 & 0.1962 \\
\hline $\mathrm{X}_{4}=$ Market Value of Equity/ Total Liabilities & 43.1798 & 46.3080 & 43.6190 & 32.4179 & 49.0082 & 42.9066 \\
\hline $\mathrm{X}_{5}=$ Sales/Total Assets & 1.1543 & 0.8580 & 0.7277 & 0.6483 & 0.6854 & 0.8147 \\
\hline Z-Score & 29.16 & 30.79 & 28.95 & 22.03 & 32.35 & 28.6560 \\
\hline
\end{tabular}

Table 1. shows the average of $\mathrm{X}_{1}, \mathrm{X}_{2}, \mathrm{X}_{3}, \mathrm{X}_{4}$ and $\mathrm{X}_{5}$ are $0.3922,0.6913,0.1962,42.9066$ and 0.8147 respectively. Now, the average Z-score for SQUARE Pharmaceuticals Ltd. can be calculated as

$\mathrm{Z}=1.2 \mathrm{X}_{1}+1.4 \mathrm{X}_{2}+3.3 \mathrm{X}_{3}+0.6 \mathrm{X}_{4}+1.0 \mathrm{X}_{5}$

The Z-score for SQUARE Pharmaceuticals Ltd. will be 28.6560 


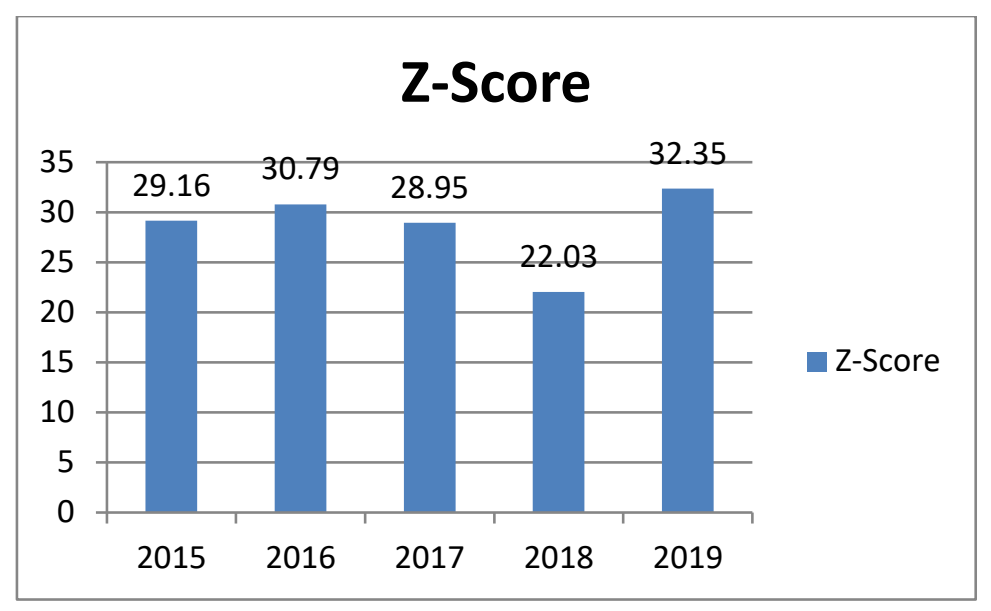

Figure 1. Graphical view of Z-Score of SQUARE Pharmaceuticals Ltd

The above graph shows that the Z-Score of SQUARE Pharmaceuticals Ltd has increased in 2016 and decreased during 2017 and 2018. Then it has increased to the highest in 2019. The results of Z Score in each study period is above 2.99, which means the company is in a safe zone and the financial performance of the company is very good, which indicates that the firm is not likely to go into bankruptcy in the future.

\section{Altman Z-Score for Renata Limited}

Table 2. Computation of Z-Score for Renata Limited

\begin{tabular}{|l|l|l|l|l|l|l|}
\hline Variable/year & $\mathbf{2 0 1 5}$ & $\mathbf{2 0 1 6}$ & $\mathbf{2 0 1 7}$ & $\mathbf{2 0 1 8}$ & $\mathbf{2 0 1 9}$ & Mean \\
\hline $\mathrm{X}_{1}=$ Net Working Capital/Total Assets & 0.0518 & 0.1148 & 0.1832 & 0.2596 & 0.3182 & 0.1855 \\
\hline $\mathrm{X}_{2}=$ Retained Earnings/Total Assets & 0.5199 & 0.5876 & 0.6449 & 0.6827 & 0.7149 & 0.6300 \\
\hline $\mathrm{X}_{3}=$ EBIT/Total Assets & 0.1951 & 0.2168 & 0.2249 & 0.2212 & 0.2231 & 0.21622 \\
\hline $\mathrm{X}_{4}=$ Market Value of Equity/ Total Liabilities & 9.6988 & 10.0945 & 12.4718 & 15.9724 & 16.3560 & 12.9187 \\
\hline $\mathrm{X}_{5}=$ Sales/Total Assets & 0.7982 & 0.8473 & 0.8852 & 0.8942 & 0.9174 & 0.8685 \\
\hline Z-Score & 8.05 & 8.58 & 10.23 & 12.47 & 12.85 & 10.4360 \\
\hline
\end{tabular}

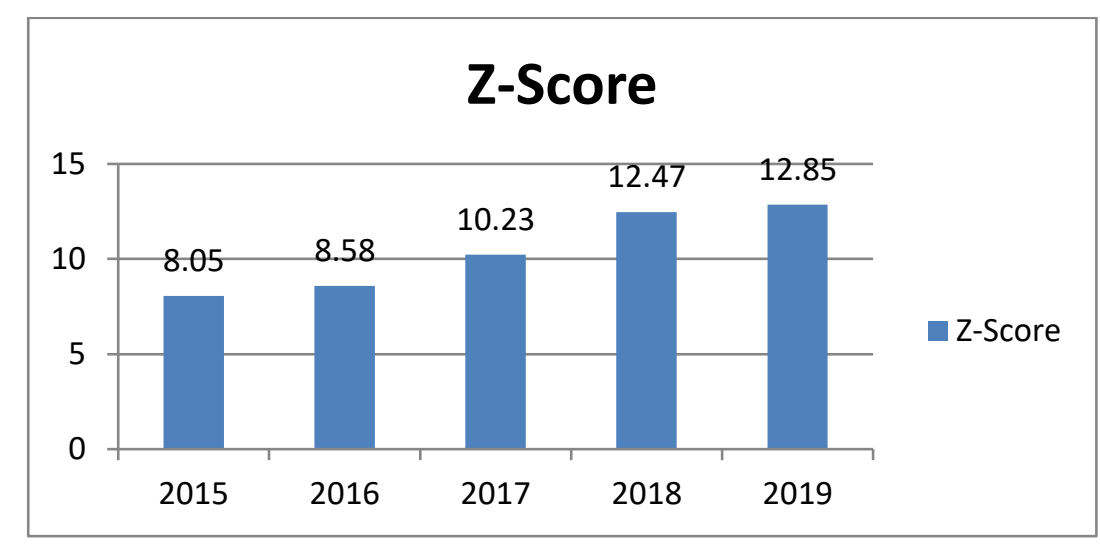

Figure 2. Graphical view of Z-Score of Renata Limited 
The above graph shows that the Z-Score has been increased throughout the study period. The result of Z-Score in each study period is above 2.99. The company is in a safe zone, which means the financial performance of the company is very good, which indicates that there is no possibility for the firm to go into bankruptcy in the near future.

\section{Altman Z-Score for Beacon Pharmaceuticals Limited}

Table 3. Computation of Z-Score for Beacon Pharmaceuticals Limited

\begin{tabular}{|l|l|l|l|l|l|l|}
\hline Variable/year & $\mathbf{2 0 1 5}$ & $\mathbf{2 0 1 6}$ & $\mathbf{2 0 1 7}$ & $\mathbf{2 0 1 8}$ & $\mathbf{2 0 1 9}$ & Mean \\
\hline $\mathrm{X}_{1}=$ Net Working Capital/Total Assets & 0.3006 & 0.2817 & 0.2520 & 0.2175 & 0.2774 & 0.2658 \\
\hline $\mathrm{X}_{2}=$ Retained Earnings/Total Assets & 0.0618 & 0.0737 & 0.0738 & 0.0828 & 0.0830 & 0.0750 \\
\hline $\mathrm{X}_{3}=$ EBIT/Total Assets & 0.0602 & 0.0527 & 0.0523 & 0.0549 & 0.0622 & 0.05646 \\
\hline $\mathrm{X}_{4}=$ Market Value of Equity/ Total Liabilities & 1.8530 & 1.9857 & 2.6514 & 2.1554 & 2.4543 & 2.2110 \\
\hline $\mathrm{X}_{5}=$ Sales/Total Assets & 0.4332 & 0,4970 & 0.5775 & 0.7662 & 0.9540 & 0.6827 \\
\hline $\mathrm{Z}$-Score & 2.19 & 2.30 & 2.75 & 2.62 & 3.09 & 2.59 \\
\hline
\end{tabular}

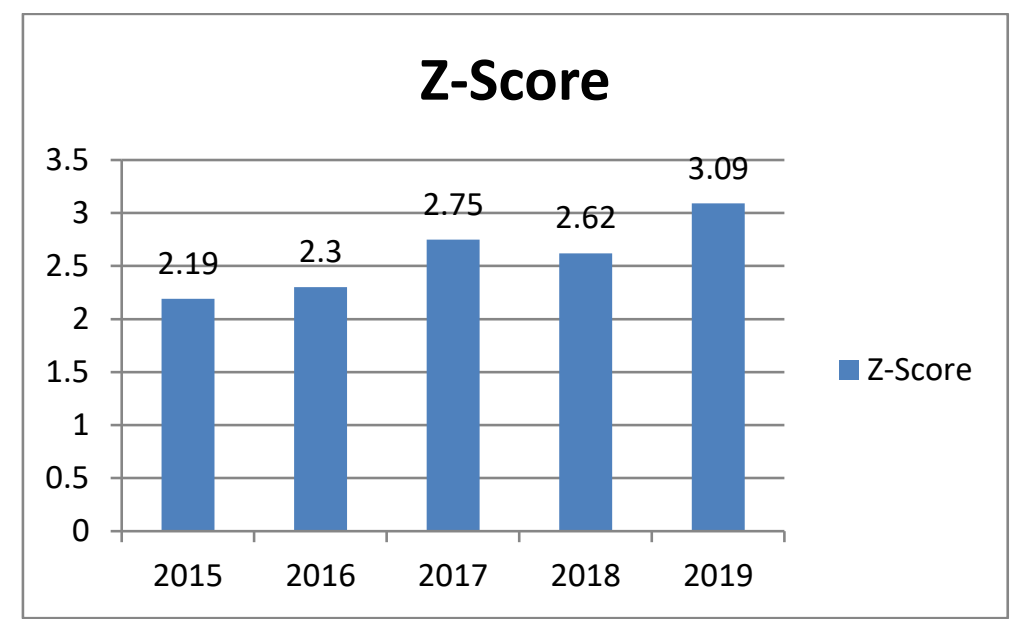

Figure 3. Graphical presentation of Z-Score of Beacon Pharmaceuticals Limited

According to the figure 3, the results of Beacon Pharmaceuticals Limited's Z Score value from 2015 to 2018 accounting years are between 1.8 and 2.99, indicating that it is the grey zone of 1.8 to 2.99. But from the next financial year it has increased, which indicates that the firm is not likely to go into bankruptcy in the future. Measures should be taken to increase the ratios of X1, X2, X3, X4 and X5 in 2019.

\section{Altman Z-Score The IBN SINA Pharmaceutical Industry Ltd}

Table 4. Computation of Z-Score The IBN SINA Pharmaceutical Industry Ltd

\begin{tabular}{|l|l|l|l|l|l|l|}
\hline Variable/year & $\mathbf{2 0 1 5}$ & $\mathbf{2 0 1 6}$ & $\mathbf{2 0 1 7}$ & $\mathbf{2 0 1 8}$ & $\mathbf{2 0 1 9}$ & Mean \\
\hline $\mathrm{X}_{1}=$ Net Working Capital/Total Assets & -0.0619 & -0.0770 & -0.0385 & -0.0830 & -0.0637 & -0.06482 \\
\hline $\mathrm{X}_{2}=$ Retained Earnings/Total Assets & 0.2216 & 0.2200 & 0.2566 & 0.3845 & 0.4107 & 0.29868 \\
\hline $\mathrm{X}_{3}=$ EBIT/Total Assets & 0.1432 & 0.1613 & 0.1548 & 0.1662 & 0.1728 & 0.15966 \\
\hline $\mathrm{X}_{4}=$ Market Value of Equity/ Total Liabilities & 2.8823 & 6.0595 & 6.0971 & 6.0196 & 6.1114 & 5.43398 \\
\hline $\mathrm{X}_{5}=$ Sales/Total Assets & 1.9573 & 2.0167 & 1.8605 & 1.9074 & 1.8612 & 1.92062 \\
\hline Z-Score & 4.40 & 6.40 & 6.34 & 6.71 & 6.60 & 6.09 \\
\hline
\end{tabular}




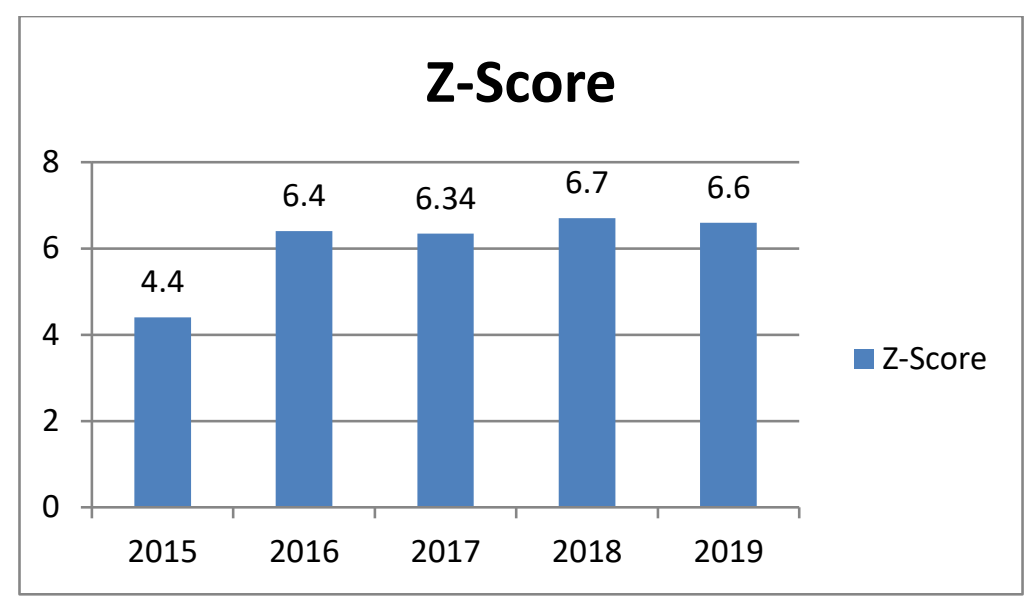

Figure 4. Graphical view of Z-Score of The IBN SINA Pharmaceutical Industry Ltd

The above graph shows that the results of Z Score in each study period is above 2.99, which means the financial performance of the company is good, which indicates that the firm is not likely to go into bankruptcy in the future.

\section{Altman Z-Score for ACI Limited}

Table 5. Computation of Z-Score for ACI Limited

\begin{tabular}{|l|l|l|l|l|l|l|}
\hline Variable/year & $\mathbf{2 0 1 5}$ & $\mathbf{2 0 1 6}$ & $\mathbf{2 0 1 7}$ & $\mathbf{2 0 1 8}$ & $\mathbf{2 0 1 9}$ & Mean \\
\hline $\mathrm{X}_{1}=$ Net Working Capital/Total Assets & 0.2279 & 0.2161 & 0.1385 & 0.0701 & 0.0791 & 0.14634 \\
\hline $\mathrm{X}_{2}=$ Retained Earnings/Total Assets & 0.3950 & 0.3728 & 0.3243 & 0.2766 & 0.2367 & 0.3211 \\
\hline $\mathrm{X}_{3}=$ EBIT/Total Assets & 0.0832 & 0.0342 & 0.0588 & 0.0470 & 0.0399 & 0.0526 \\
\hline $\mathrm{X}_{4}=$ Market Value of Equity/ Total Liabilities & 3.2166 & 2.1778 & 1.7701 & 0.8112 & 0.5035 & 1.6958 \\
\hline $\mathrm{X}_{5}=$ Sales/Total Assets & 0.7525 & 0.3762 & 0.6766 & 0.5993 & 0.5238 & 0.5857 \\
\hline Z-Score & 3.78 & 2.58 & 2.55 & 1.71 & 1.38 & 2.4 \\
\hline
\end{tabular}

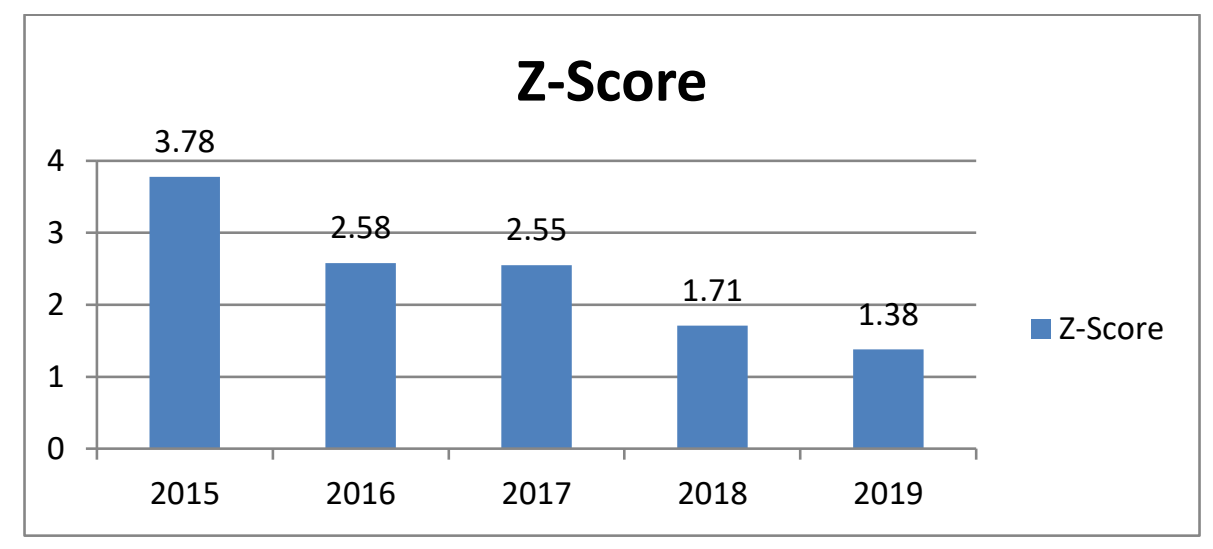

Figure 5. Graphical presentation of Z-Score of ACI Limited

From figures, it is found that analysis reveals that $\mathrm{z}$ scores have been declining from 3.78 (2015) to 1.38 (2019) for ACI limited. Although the $\mathrm{z}$ score value was greater than 2.99 in 2015, it indicated that ACI Limited was in a safe zone with a good financial position, but the company entered the grey zone ( $Z$ 2.99) in 2016 and 2017 by decreasing the $z$ score values from 3.78 to 2.58 and 2.55.The company has reached the bankruptcy zone $(\mathrm{Z} 1.8)$ with $\mathrm{z}$ scores of 1.71 and 1.38 respectively 
in the next two years, 2018 and 2019. The more poor z score indicates that the firm's performance became poorer due to the decline of total assets, market value of shares, EBIT and liquid assets in terms of total assets and total liabilities during the period of study. It can be predicted from the declining $\mathrm{z}$ scores that the company is going to be bankrupt in the near future.

\section{Altman Z-Score for Ambee Pharmaceuticals Ltd}

Table 6. Computation of Z-Score for Ambee Pharmaceuticals Ltd

\begin{tabular}{|l|l|l|l|l|l|l|}
\hline \multicolumn{1}{|c|}{ Variable/year } & $\mathbf{2 0 1 5}$ & $\mathbf{2 0 1 6}$ & $\mathbf{2 0 1 7}$ & $\mathbf{2 0 1 8}$ & $\mathbf{2 0 1 9}$ & Mean \\
\hline $\mathrm{X}_{1}=$ Net Working Capital/Total Assets & 0.0411 & -0.0674 & -0.0960 & -0.0924 & -0.1039 & -0.0637 \\
\hline $\mathrm{X}_{2}=$ Retained Earnings/Total Assets & 0.0668 & 0.0721 & 0.0696 & 0.0732 & 0.0712 & 0.0706 \\
\hline $\mathrm{X}_{3}=$ EBIT/Total Assets & 0.0567 & 0.0853 & 0.0652 & 0.0440 & 0.0539 & 0.0610 \\
\hline $\mathrm{X}_{4}=$ Market Value of Equity/ Total Liabilities & 1.7966 & 1.9129 & 2.4921 & 3.7170 & 4.0875 & 2.8012 \\
\hline $\mathrm{X}_{5}=$ Sales/Total Assets & 0.7882 & 1.2128 & 0.7791 & 0.7871 & 0.7971 & 0.8729 \\
\hline Z-Score & 2.20 & 2.66 & 2.47 & 3.15 & 3.40 & 2.776 \\
\hline
\end{tabular}

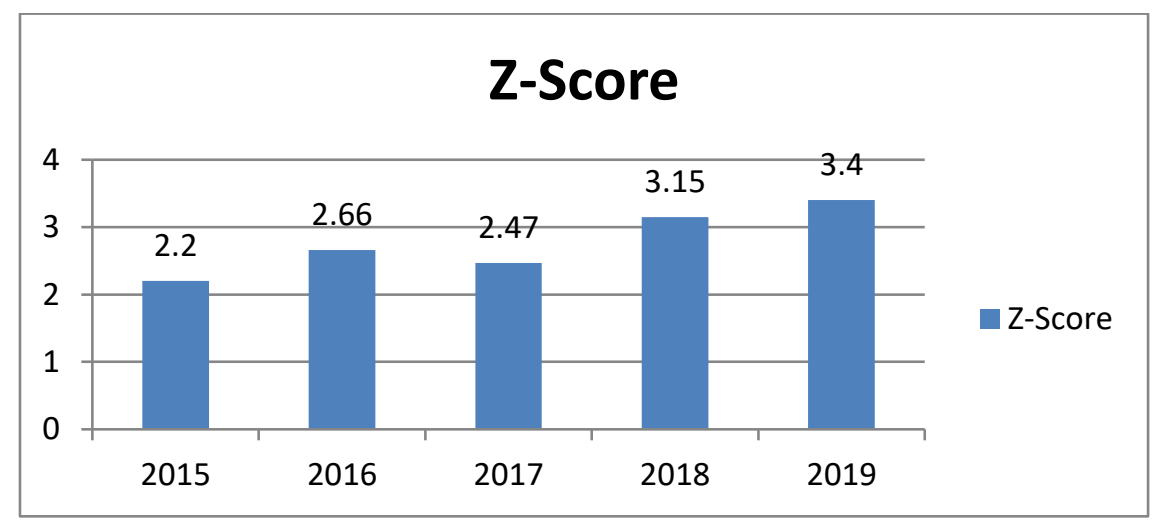

Figure 6. Graphical view of Z-Score of Ambee Pharmaceuticals Ltd

From figure 6, the results of Z Score value of Ambee Pharmaceuticals Ltd from 2015-2017 is below 2.99, which indicates that it is entered in the grey zone $(1.8<\mathrm{Z2.99})$. But from the next financial years it has increased and moved to a safe zone, which indicates that the firm is not likely to go into bankruptcy in the future.

\section{Altman Z-Score for Beximco Pharmaceuticals Ltd}

Table 7. Computation of Z-Score for Beximco Pharmaceuticals Ltd

\begin{tabular}{|l|l|l|l|l|l|l|}
\hline Variable/year & $\mathbf{2 0 1 5}$ & $\mathbf{2 0 1 6}$ & $\mathbf{2 0 1 7}$ & $\mathbf{2 0 1 8}$ & $\mathbf{2 0 1 9}$ & Mean \\
\hline $\mathrm{X}_{1}=$ Net Working Capital/Total Assets & 0.1109 & 0.1780 & 0.1680 & 0.0532 & 0.0105 & 0.1041 \\
\hline $\mathrm{X}_{2}=$ Retained Earnings/Total Assets & 0.3276 & 0.3440 & 0.3688 & 0.3340 & 0.3484 & 0.3446 \\
\hline $\mathrm{X}_{3}=$ EBIT/Total Assets & 0.0925 & 0.1431 & 0.1012 & 0.0921 & 0.1029 & 0.1064 \\
\hline $\mathrm{X}_{4}=$ Market Value of Equity/ Total Liabilities & 3.8870 & 4.1862 & 5.0854 & 2.3220 & 1.7540 & 3.4470 \\
\hline $\mathrm{X}_{5}=$ Sales/Total Assets & 0.4205 & 0.6432 & 0.4550 & 0.4051 & 0.4636 & 0.4775 \\
\hline $\mathrm{Z}$-Score & 3.65 & 4.32 & 4.56 & 2.63 & 2.36 & 3.504 \\
\hline
\end{tabular}




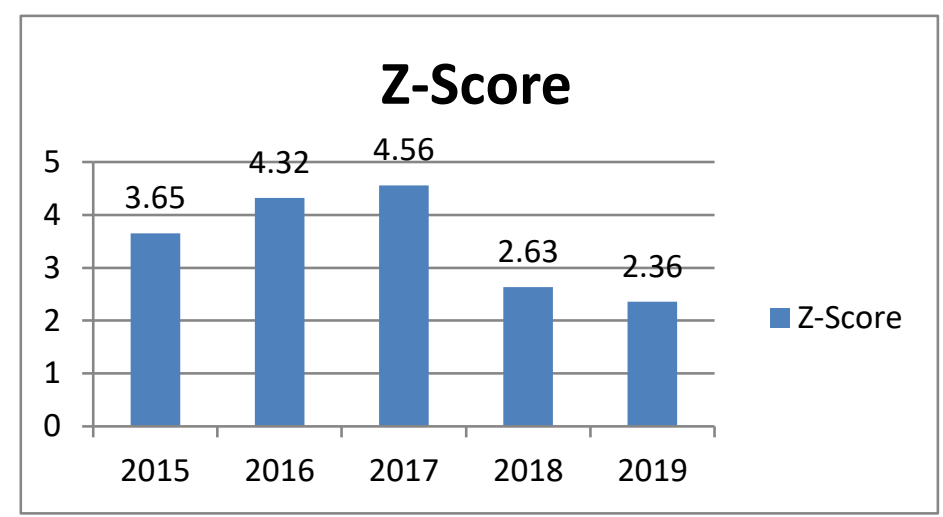

Figure 7. Graphical presentation of Z-Score of Beximco Pharmaceuticals Ltd

The results of Z-Score value of Beximco Pharmaceuticals Ltd shows that the company is in the safe zone during 2015, 2016 and 2017 as the score is above 2.99. But from 2018-2019 the score is below 2.99, which indicates that it is in a grey zone of 1.8 to 2.99 , which indicates that the firm is in a moderate zone of bankruptcy and steps must be taken before it goes to bankruptcy in the future.

\section{Comparative Analysis}

Table 8. Summary of Company's ranking based on activities and ratios

\begin{tabular}{|c|c|c|c|c|c|c|c|}
\hline $\begin{array}{l}\text { Company's } \\
\text { Indicators }\end{array}$ & $\begin{array}{c}\text { SQUARE } \\
\text { Pharmaceuticals } \\
\text { Ltd }\end{array}$ & $\begin{array}{c}\text { Reneta } \\
\text { Ltd }\end{array}$ & $\begin{array}{c}\text { Beacon } \\
\text { Pharmaceuticals } \\
\text { Ltd }\end{array}$ & $\begin{array}{c}\text { The IBN SINA } \\
\text { Pharmaceutical } \\
\text { Industry Ltd }\end{array}$ & $\begin{array}{c}\text { ACI } \\
\text { Ltd }\end{array}$ & $\begin{array}{c}\text { Ambee } \\
\text { Pharmace } \\
\text { uticals Ltd }\end{array}$ & $\begin{array}{c}\text { Beximco } \\
\text { Pharmace } \\
\text { uticals Ltd }\end{array}$ \\
\hline Avg. of $\mathbf{X}_{\mathbf{1}}$ & 1 & 3 & 2 & 7 & 4 & 6 & 5 \\
\hline Avg. of $\mathbf{X}_{\mathbf{2}}$ & 1 & 2 & 6 & 5 & 4 & 7 & 3 \\
\hline Avg. of $\mathbf{X}_{\mathbf{3}}$ & 2 & 1 & 6 & 3 & 7 & 5 & 4 \\
\hline Avg. of $\mathbf{X}_{\mathbf{4}}$ & 1 & 2 & 6 & 3 & 7 & 5 & 4 \\
\hline Avg. of $\mathbf{X}_{\mathbf{5}}$ & 4 & 3 & 5 & 1 & 6 & 2 & 7 \\
\hline
\end{tabular}

SQUARE Pharmaceuticals Ltd is ranked first on net working capital to total asset ratio, retained earnings to total asset ratio and market value of equity to total liabilities. It is ranked second on EBIT to total assets and fourth on sales to asset ratio. The performance of the company is good and can increase its sales for holding best position. Renata Ltd is ranked first on EBIT to total asset, second on retained earnings to total assets and market value to total liabilities. It has ranked third on net working to total assets and sales to total assets ratio. The company is performing well. Beacon Pharmaceuticals Ltd is ranked second on net working capital to total asset, fifth on sales to total assets ratio. It has ranked sixth on retained earnings to total asset ratio EBIT to total asset and market value of equity to total liabilities. The company is not performing well. The IBN SINA Pharmaceuticals Ltd is ranked first on sales to total assets ratio, third on EBIT to total asset and market value of equity to total liabilities. It is ranked fifth on retained earnings to total asset ratio and seventh on net working capital to total asset ratio. The company has to work on its retained earnings and net working capital policy. ACI Ltd is ranked fourth on net working capital to total asset ratio and retained earnings to total asset ratio SQUARE Pharmaceuticals Ltd is ranked first on net working capital to total asset ratio, retained earnings to total asset ratio and market value of equity to total liabilities. It is ranked second on EBIT to total assets and fourth on sales to asset ratio. The performance of the company is good and can increase its sales to hold the best position. Renata Ltd is ranked first on EBIT to total assets, second on retained earnings to total assets and market value to total liabilities. It has ranked third on net working to total assets and sales to total assets ratio. The company is performing well. 
Beacon Pharmaceuticals Ltd is ranked second on net working capital to total assets, fifth on sales to total assets ratio. It has ranked sixth on retained earnings to total asset ratio EBIT to total assets and market value of equity to total liabilities. The company is not performing well. IBN SINA Pharmaceuticals Ltd is ranked first on sales to total assets ratio, third on EBIT to total assets and market value of equity to total liabilities. It is ranked fifth on retained earnings to total asset ratio and seventh on net working capital to total asset ratio. The company has to work on its retained earnings and net working capital policy. ACI Ltd is ranked fourth on net working capital to total asset ratio and retained earnings to total asset ratio. It is ranked sixth on sales to total assets ratio, seventh on EBIT to total assets and market value of equity to total liabilities. The performance of the company is poor. Ambee Pharmaceuticals Ltd is ranked second on sales to total assets ratio, fifth on EBIT to total asset and market value of equity to total liabilities, sixth on net working capital to total asset ratio and seventh on retained earnings to total asset ratio. The performance has to be improved. Beximco Pharmaceuticals Ltd is ranked third on retained earnings to total asset ratio. It is ranked fourth on EBIT to total assets and market value of equity to total liabilities, fifth on net working capital to total asset ratio and seventh on sales to total assets ratio.

From Table 8, it is clear that SQUARE Pharmaceuticals Ltd tops the list among all other companies. Renata Ltd is performing well but unable to perform at the same pace.

Table 9. Company's Z-Score at a glance

\begin{tabular}{|c|c|c|c|c|c|c|}
\hline Company/Year & $\mathbf{2 0 1 5}$ & $\mathbf{2 0 1 6}$ & $\mathbf{2 0 1 7}$ & $\mathbf{2 0 1 8}$ & $\mathbf{2 0 1 9}$ & Average \\
\hline SQUARE Pharmaceuticals Ltd & 29.16 & 30.79 & 28.95 & 22.03 & 32.35 & 28.66 \\
\hline Reneta Limited & 8.05 & 8.58 & 10.23 & 12.47 & 12.85 & 10.44 \\
\hline Beacon Pharmaceuticals Limited & 2.19 & 2.30 & 2.75 & 2.62 & 3.09 & 2.59 \\
\hline The IBN SINA Pharmaceutical Industry Ltd & 4.40 & 6.40 & 6.34 & 6.71 & 6.60 & 6.09 \\
\hline ACI Limited & 3.78 & 2.58 & 2.55 & 1.71 & 1.38 & 2.40 \\
\hline Ambee Pharmaceuticals Ltd & 2.20 & 2.66 & 2.47 & 3.15 & 3.40 & 2.78 \\
\hline Beximco Pharmaceuticals Ltd & 3.65 & 4.32 & 4.56 & 2.63 & 2.36 & 3.50 \\
\hline
\end{tabular}

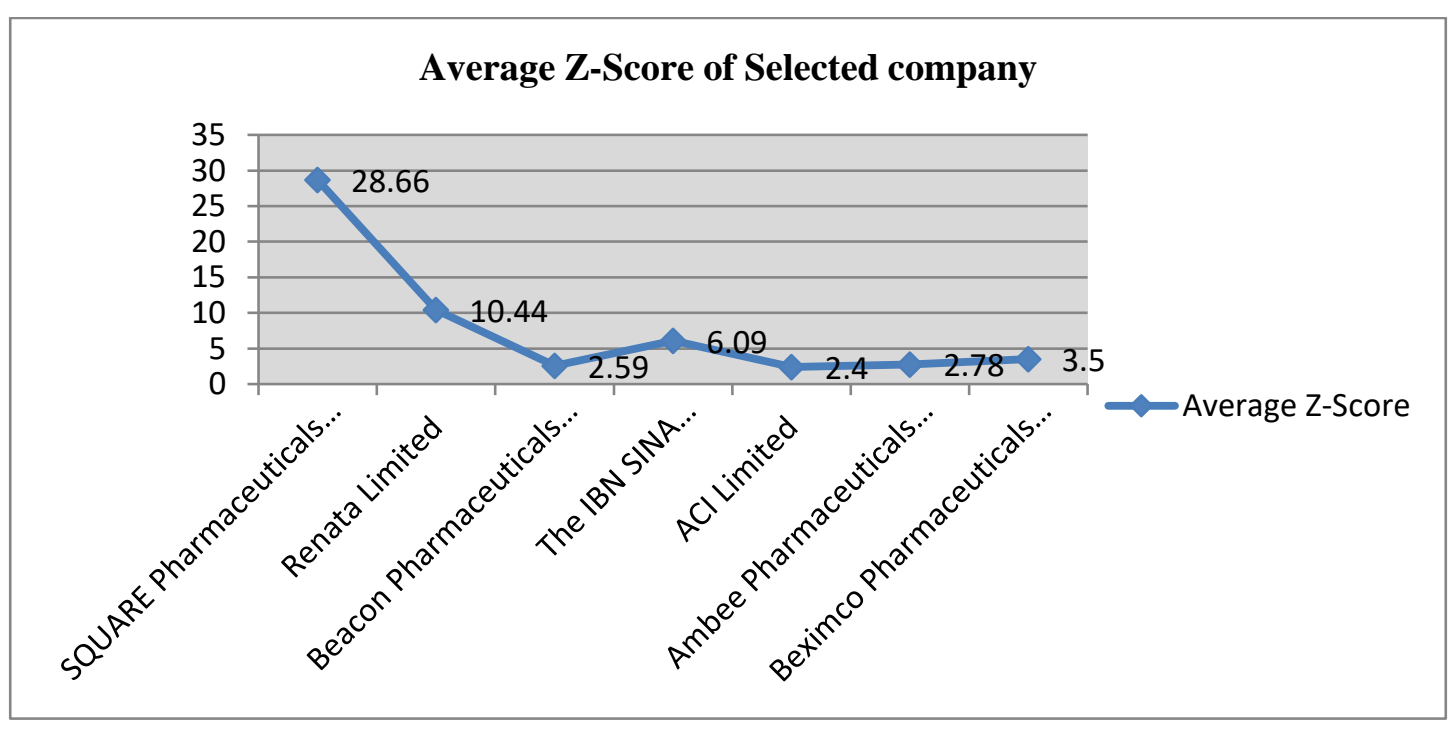

Figure 8. Graphical presentation of Average Z-Score of the Companies 
The above graph shows that the Z-Score value of SQUARE Pharmaceuticals Ltd is above average in all the years except in 2018, which is 22.03. Renata Limited and Ambee Pharmaceuticals Ltd's Z-Score values were low from 2015-2017 and then they have increased above average for the next two years. The Z-Score value of Beacon Pharmaceuticals Limited is low from 2015-2018 and it has increased above average in 2019, which is 3.09. The IBN SINA Pharmaceutical Industry Ltd had a low value of 4.40 in 2015 and it stood above average for the last four years. ACI Limited and Beximco Pharmaceuticals Ltd's Z-Score value stood above the average for the first three years and then it started declining.

Overall, SQUARE pharmaceutical Limited has higher Z-Score values than other companies, which indicates that the company is in a very good position. Renata Limited and The IBN SINA Pharmaceutical Industry Ltd also have higher scores than other companies, which indicate a good position for investment.

\section{Summary of Findings}

\section{RESULT \& CONCLUSION}

- Z-Score of SQUARE Pharmaceuticals Ltd has increased in 2016 and decreased during 2017 and 2018. Then it has increased to the highest in 2019. The results of Z-Score in each study period are above 2.99 .

- Z-Score of Renata Limited has increased throughout the study period. The result of Z-Score in each study period is above 2.99

- The results of Z-Score value of Beacon Pharmaceuticals Limited from 2015-2018 is below 2.99 , which indicates that it is in the grey zone of 1.8 to 2.99 . But from the next financial year it has increased.

- The results of Z-Score of The IBN SINA Pharmaceutical Industry Ltd in each study period are above 2.99 .

- The analysis of ACI reveals that z scores varied between 3.78 (2015) to 1.38 (2019). In 2015, the company was in the safety zone $(Z>2.99)$ and from 2017 onwards the company is in the grey zone $(Z<2.99)$ except in 2018 and 2019.

- The results of Z-Score value of Ambee Pharmaceuticals Ltd from 2015-2017 is below 2.99, which indicates that it is in the grey zone of 1.8 to 2.99 . But from the next financial years it has increased.

- The results of Z-Score value of Beximco Pharmaceuticals Ltd shows that the company is in the safe zone during 2015, 2016 and 2017 as the score is above 2.99. But from 2018-2019 the score is below 2.99, which indicates that it is in the grey zone of 1.8 to 2.99 .

- The Z-Score value of SQUARE Pharmaceuticals Ltd is above average in all the years except in 2018, which is 22.03. Renata Limited and Ambee Pharmaceuticals Ltd's Z-Score values were low from 2015-2017 and then they have increased above average for the next two years. The Z-Score value of Beacon Pharmaceuticals Limited is low from 2015-2018 and it has increased above average in 2019, which is 3.09. The IBN SINA Pharmaceuticals Industry Ltd had a low value of 4.40 in 2015 and it stood above average for the last four years.

- Overall, SQUARE Pharmaceuticals Limited has higher Z-Score values than other companies and tops the lists in all aspects, which indicates that the company is in a very good position. Renata Limited and The IBN SINA Pharmaceuticals Industry Ltd also have higher scores than other companies, which indicate a good position for investment.

\section{RECOMMENDATIONS \& CONCLUSION}

From the above study, it has been seen that SQUARE Pharmaceuticals Ltd, Renata Limited and The IBN SINA Pharmaceuticals Limited hold a very good position with the highest score, which is above 2.99. Beacon Pharmaceuticals Limited was in the grey zone from 2015 to 2018 and only moved to the safe zone in 2019, indicating that the firm expects to be risky. Ambee Pharmaceuticals Limited 
shows improvement year by year. BEXIMCO Pharmaceuticals Limited remains a grey zone that increases the chance of bankruptcy, so measures must be taken to increase its overall performance. ACI Limited has a very poor Z-Score and headed the company to the bankruptcy zone. The company has a higher chance of going bankrupt in the future. Proper measures must be taken to improve the condition of the distressed companies. Management must give a close look at the various indicators used in the test in order to bring succession to the company. For each selected company, some suggestions are provided below.

- Beacon Pharmaceuticals Limited has been in the grey zone for the majority of the years, so it must improve sales revenue, which will improve EBIT in the future, and thus the company's Z-Score. The company should also take care of its market price of shares to increase the Z-Score and must look at its working capital and try to increase its current assets.

- The IBN SINA Pharmaceuticals must focus on its sales to hold the position.

- ACI Limited has a very poor score, so it must increase the market value of its share. There must be an adequate proportion of EBIT to total assets. The company must increase its liquid assets in order to increase net working capital and retained earnings must be increased in order to increase its Z-Score.

- Ambee Pharmaceuticals Limited was in the grey zone for the first three years, so it must work on its working capital policy. It must make more contribution to its retained earnings.

- Beximco Pharmaceuticals Ltd must increase its liquid assets and increase its sales through new drug development.

- All companies must utilize their assets properly and must have realistic goals and efficient management. There must be sufficient research and development on the products. The companies must hire skilled manpower.

- Measures must be taken to overcome power disruption and trouble with machinery. There must be sufficient availability of raw materials and the number of shares must also be increased.

Bangladesh is one of the least developed countries which meets up to $98 \%$ of its demand for pharmaceutical products. It has a market size of nearly BDT 200 billion. Bangladeshi pharmaceutical products are exported to 147 countries. This industry contributes about $1.85 \%$ of total GDP. The industry has undergone remarkable transformations in recent years, and it is now the most successful manufacturing industry in the country.

\section{REFERENCES}

ACI Limited. (August 10, 2020). Company profile. Retrieve from https://www.aci-bd.com/aboutus/company-profile.html

Ahmmed, M., \& Hassan, R. (2019). Performance Evaluation of Some Selected Pharmaceutical Companies in Bangladesh - A Comparative Analysis. Retrieve from https://www.researchgate.net/publication/335826987_Performance_Evaluation_of_Some_Sele cted_Pharmaceutical_Companies_in_Bangladesh_-_A_Comparative_Analysis

Akbar, B. M. B., Achsani, N. A., \& Maulana, T. N. A. (2019). Financial Distress of Pharmaceutical Companies in Indonesia. International Journal of Finance and Banking Research, 5(6), 174-179.

Al Ali, M. S. (2018). The Application of Altman's Z-Score Model in Determining the Financial Soundness of Healthcare Companies Listed in Kuwait Stock Exchange. International Journal of Economic Papers, 3(1), 1-5. 
Al-Rawi, K., Kiani, R., \& Vedd, R. R., (2018). The Use Of Altman Equation For Bankruptcy Prediction In An Industrial Firm (Case Study). International Business \& Economics Research Journal, 7(7), 2018.

Altman's Z-Score Model. (August 3, 2020). CFI. Retrieve from https://corporatefinanceinstitute.com/about-cfi/

Ambee Pharmaceuticals Ltd. (August 5, 2020). Company profile. Retrieve from https://www.ambeepharma.com/company_profile

Beacon Pharmaceuticals Limited. (August 5, 2020). About us. Retrieve from https://www.beaconpharma.com.bd/about-us/

Beximco Pharma. (August 10, 2020). About us. Retrieve from https://beximcopharma.com/about.html

Dakhwani, M. J. P., \& Nayak, D. K. (2017) Financial Distress Analysis of Selected Indian Pharmaceutical Companies . IJEMR, 7(10), 2017.

Faisal, M. A. (2019). Pharmaceutical Industry of Bangladesh: A Multi-Billion Dollar Industry. Eastern Bank Limited Securities Ltd, Dhaka, 2019. Retrieve from https://www.arx.cfa/ /media/2A85F9B2CEAB43CFAF325AB54F3EF404

Geethalakshmi, A., \& Jothi, K. (2017). Financial Health of Select Indian Pharmaceutical Companies through Z-Score Model. International Journal of Pure and Applied Mathematics, 117(15), $69-78$.

Jannatunnesa, M. (2016). Performance Analysis of Financial Soundness and Determinants of Profitability of Pharmaceutical Industry in Bangladesh. Journal of Business Studies, 37(1), 2016.

Majumder, M. T. H., \& Rahman, M. M. (2011). Financial Analysis of Selected Pharmaceutical Companies in Bangladesh. Journal of Biology, Agriculture and Healthcare, 1(1).

Mizan, A.N.K., \& Hossain, M. M. (2014). Financial Soundness of Cement Industry of Bangladesh: An Empirical Investigation Using Z-score. American Journal of Trade and Policy, 1(1), 16-22.

Mizan, A.N.K., Amin, M. R., \& Rahman, T. (2011). Bankruptcy Prediction by Using the Altman Zscore Model: An Investigation of the Pharmaceutical Industry in Bangladesh. Bank Parikrama, $36(2-4), 33-56$.

Niti, N. S. (2019). Potentials of Bangladesh Pharmaceutical Industry: A Comparative Study. Global Journal of Human-Social Science: H Interdisciplinary, 19(1).

Nsiah, F., \& Aidoo, P. (2015). Financial Performance of Listed Pharmaceutical Companies on Ghana Stock Exchange. Research Journal of Finance and Accounting, 6(2), 2015.

Panda, J. K. \& Behera, P. (2015). Financial Distress Prediction of Pharmaceutical Industry through ZScore Model. International Journal of Research in Commerce and Management, 6(2), 2015.

Ray, S. (2011). Assessing Corporate Financial Distress in Automobile Industry of India: An 
Application of Altman's Model. Research Journal of Finance and Accounting, 2(3).

Renata Limited. (August 5, 2020). About us. Retrieve from https://renata-ltd.com/about-us/

Square Pharmaceuticals Ltd. Bangladesh. (August 3, 2020). About us. Retrieve from http://www.squarepharma.com.bd/about-us.php

The IBN SINA Pharmaceutical Industry Ltd. (August 6, 2020). Company overview. Retrieve from http://www.ibnsinapharma.com/about/company-overview/

\section{Copyrights}

Copyright for this article is retained by the author(s), with first publication rights granted to the journal. This is an open-access article distributed under the terms and conditions of the Creative Commons Attribution license (http://creativecommons.org/licenses/by/4.0/) 